\title{
Spatial Pattern of Crime with Geographic Information System (GIS) in Makassar, Indonesia
}

\author{
Muhammad Ichsan Ali ${ }^{1}$, Muhammad Rais ${ }^{2}$ \\ ${ }^{1}$ Universitas Negeri Makassar, Department of Civil Engineering Education and Planning, Makassar 90222, Indonesia \\ ${ }^{2}$ Universitas Negeri Makassar, Department of Geography Education, Makassar 90222, Indonesia
}

\begin{abstract}
The development success promoted by an area depends on the size of the obstacles of crime. Society must have been very familiar with the figure of a group of teenagers who called himself a motorcycle gang. They like artists who are and are always rising in the art of crime. They regard evil as the beauty of their loyalty to fellow motorcycle gang members. Solidarity, more intimate friendship is considered harmful by society. The purpose of this study is to evaluate whether there is a relationship between the level of crime with the density and the number of people living in a particular area in Makassar. By using survey method and data collection technique that is snowball sampling, then for analysis of distribution pattern of hotspot criminal using ArcGIS software aid with Density Mapping method, while to see spatial relationship pattern of criminality to the amount and population density using SPSS software and overlay method. The results show that the design of distribution of criminal hotspots in 2015 and 2016 with the design of hotspots clusters that spread in areas of high and medium population density. Then there is a significant relationship between population density and criminal hotspots. In 2015, the distribution pattern of crime hotspots concentrated in areas with high population density, but by 2016 the distribution pattern of crime hotspots spread evenly not only in high population density areas but has spread to the medium population density area.
\end{abstract}

Keywords: CrimeHot Spots, Population Density, Geographic Information System (GIS)

\section{Introduction}

Geographical Information System as one of the technologies developed at this time can use as a tool to help generate data and information on crime will be more readily understood and can be spatially mapped using Geographic Information System (GIS) [1], [2].

Identification of areas of crime through mapping and targeting police activities to these places, it has been recognized in the evaluation of high-quality research as a useful technique against crime[3].A method developed to predict and identify locations where new crimes that might occur through mapping [4]. From that information will help law enforcement agencies to allocate resources in the region [5] strategically. Then the info or criminal news can be used as a good data source to create crime distribution data in an area if we can extract the crime scene.

Crime occurs in "hot spots" that are supported by a particular region of choice, the statement supported by research conducted by [6]-[9], andthis based on the day-to-day experience of criminal analysts from law enforcement agencies across the country. Identifying crime points shows where the action is focused. It connects this to the more difficult environmental context for spatial analysis [10]. Attempts to predict the scene in the future need serious consideration of this issue.

In general, many biological approaches [11], are the view that crime opportunities are heterogeneous across the region [12].An important concept emerging from the field of environmental criminal research is "environmental backcloth" [13], and environmental support to study criminal cases including social and cultural dimensions, Law, spatial and temporal. This support also explicitly covers the physical infrastructure of buildings, roads, transportation systems, land use, design and construction and that lies within their physical infrastructure. In the concept of environmental crime studies, it will be labeled "a myriad of factors that surround individuals, are part of the individual, influenced by criminal activity, or which may affect criminal activity"[14].

From some experts on probability theory [15], [16], more than 30 years shows that the type of crime explains the variationin crime opportunities where criminals can access it. Although theoretically well developed, the study limited by the ability to manipulate the odds and develop indicators to evaluate them [17]. [18], explains that the risk of crime victims varies widely depending on the location and the environment and their place of residence.

The city of Makassar which is the center of government and the economy must not separate from various acts of criminality. Based on the explanation of experts crime rate itself is influenced by the opportunity to be a [19], free will, the decisions hedonistic, and failure to make social contract [20], the properties of antisocial innate [21], the punishment given to actors disproportionately [22], and poverty is one of the factors that influence why criminal it happen.

The police authority must prevent and reduce crime rates in its jurisdiction. Prevention and anticipation of criminal acts in big cities such as Makassar with manual recording method are not ideal anymore done. The police are responsible for handling criminal offenses in their legal areas, but currently, the police are having problems with data recording systems and criminal data spreading in all police divisions[23]. All forms of current crime events still recorded in tabular statistics. In this way it cannot be represented spatially, so decision making for case handling for all Makassar City police stations becomes difficult and takes a long time.

The role of population density as a source of crime or as a 


\section{International Journal of Science and Research (IJSR) \\ ISSN (Online): 2319-7064}

Index Copernicus Value (2016): 79.57 | Impact Factor (2017): 7.296

barrier has been the subject of many investigations, studies, and debates over the past few years.[24]. Unfortunately, this discussion is confused by variations in the definition of density, the variety of the type of crime associated with it.

Increasing complexity introduced by the existence of many categories of crime, each with its situation change.In the 1970s-1980s, based on the rat experiments of [25], there was a famous view that was once very popular but now unreliable, that high population density and expressed in densely populated forms would lead to violent aggression and increased levels criminality.Other studies tend to show population density indicators as a more general factor, and SES (socioeconomic conditions) is considered a significant factor in the cause of crime[24], [26]-[29].Additional research and study on density and crowd can be seen on [30]-[32]. The purpose of this survey is to evaluate the relationship between frequency and crime, and whether many people are living in the Makassar area.

\section{Literature Review}

\subsection{Criminality}

Criminal acts are unlawful and not by the rules and norms (deviations) that have agreed upon in a society[33]. New criminologists consider that deviant behavior is called a crime which must explain by looking at the structural conditions in the community in the context of inequality of power, authority, and prosperity and its relation to various economic and political changes that exist in the population[34]. In committing a crime, several factors influence the criminals to do such actions[35]. The various elements are poverty, employment, and the character of the perpetrator who committed the crime. Also, other factors are affecting the incidence of crime, namely population density, number of police patrols, road conditions and environment, the frequency of neighborhood patrols, and other factors [36]. In Indonesia, crime has become one of the focus of the police for the achievement of security and comfort in the community.

\subsection{Geographic Information System (SIG)}

Dr. Tomlinson first created geography Information System then introduced it in the early 1960's in Canada. Initially, the system was intended to collect, store and then analyze the potential and capabilities possessed by land in the interior. In the past, mapping by the use of Computers usedas a box. But, this is a method that has many limitations. Later in the late 1980s, the use of GIS has become very popular and has even been used by other disciplines with close links to GIS, as well as a benchmark in industry development [37]. According to [38], SIG is a computer system capable of collecting, storing, manipulating, and displaying information geographically. Meanwhile, according to [39], Geographic Information System (GIS) is a set of computer tools used to map and analyze the things or events that occur on earth. GIS technology connects databases such as using statistical analysis then visualizes in map form [40].

\subsection{Criminal Mapping}

Criminal mapping is an activity of processing and controlling spatial criminal data whose output visually displayed according to the needs of the user[41]. Illegal mapping can provide information about a particular hot spot location or know the amount of a specific criminal action reported. Criminal mapping is part of the criminal analysis [2].This mapping has three roles in the criminalinvestigation. The questions are:

a) Provide visual analytics and statistical analysis

b) As a bridge to connect supporting data such as census data, population data and location data of police posts.

c) Displays the output as visual.

\subsection{Type of Crime Mapping}

There are several types of criminal mapping [2]. The mapping includes:

a) Single symbol mapping, this mapping uses a symbol only to indicate a particular event symbol. The downside of this mapping is that events in the same place that occur more than once cannot see. This type of mapping is not suitable for mapping criminal events that usually happen more than once on one occasion.

b) Density Mapping, using shading to show the intensity of the incident in a particular place. The darker the shaded area, the more events there are.

c) The buffer is an area around the point/location. The shield can be arranged for its coverage area, be small or large, according to the needs and scale of the map.

d) Graduated Mapping, two types in graduated mapping is graduated color mapping and graduated point mapping. The larger the point size or,the darker an event occurs.

e) Chart Mapping, chart mapping can display multiple values at once in a variable. For example, the variable is a criminal,and its value is hunting, murder, and rape. There are two types of chart mapping, the pie chart,and the chat bar.

f) Interactive mapping, this technique is not a mapping technique but a technique for conveying information that has encapsulated to the user. The results of the analysis that has made can displayon the website or stand-alone system.

g) Crime Density, crime density is calculated by dividing the number of events of each type of criminality within the territory of authority by the scope of its area within a few miles.

\section{Methods}

\subsection{Research sites}

The study area located between $119^{0} 24^{\prime} 17^{\prime} 38$ "East Longitude and $508^{0} 6^{\prime} 19^{\prime \prime}$ South Latitude where Maros Regency borders the north, to the east adjacent to MarosRegency in the south, GowaRegency in the west, Makassar adjoining on the west. Makassar City has an area of $175.77 \mathrm{Km}^{2}$ covering 14 subdistricts, where Biringkaya District is the most extensive district of $48.22 \mathrm{~km} 2$, followed by Tamalanrea District with an area of $31.84 \mathrm{~km} 2$, Manggala with an area of $20.21 \mathrm{~km}^{2}$ and Tamalate District with an area of $20.21 \mathrm{~km}^{2}$. While the District Mariso is the smallest

Volume 7 Issue 4, April 2018 www.ijsr.net 


\section{International Journal of Science and Research (IJSR) \\ ISSN (Online): 2319-7064 \\ Index Copernicus Value (2016): 79.57 | Impact Factor (2017): 7.296}

district with an area of $1.82 \mathrm{~km}^{2}$, followed by District Wajo with an area of $1,99 \mathrm{~km}^{2}$, and Bontoala with an area of 2.10 $\mathrm{km}^{2}$. The population density of the year 2016 amounted to 8,360 people per square kilometer. Thearea and population density of the study sites can see in Figure 1.

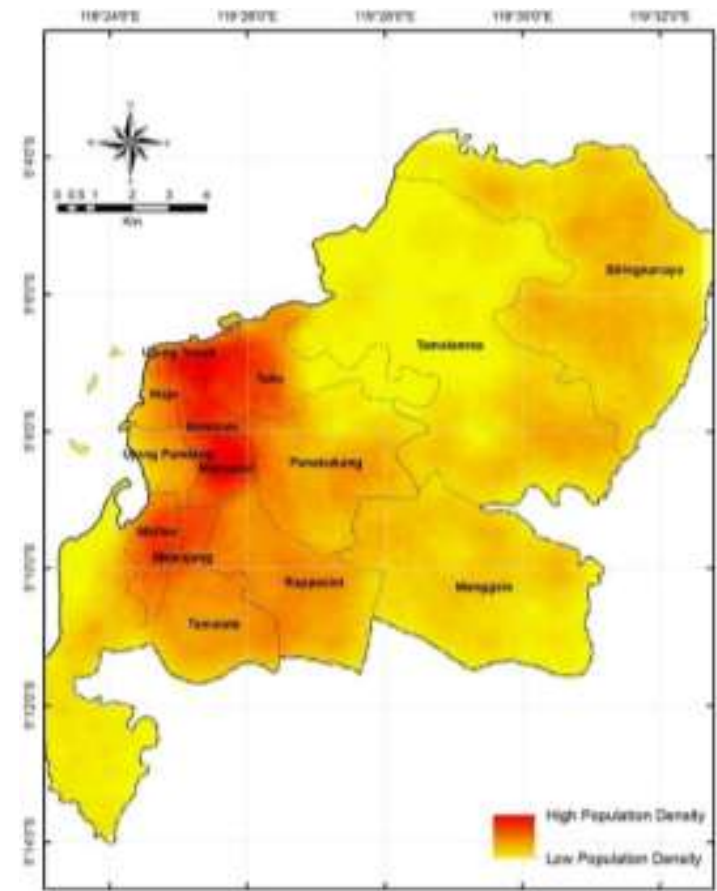

Figure 1: The population density of Makassar City

\subsection{Research Approach and Procedures}

Our technique for establishing and improving several risk factors in a spatial context. Data from Irvington are involved in GIS to produce maps that allow for the future[42], [43]. Raster mapping uses a grid consisting of the same cells to represent continuous discrete or spatial data. Any real-world coordinate difference and attribute value. When different raster maps have the same size, this map can be used by adding, subtracting, multiplying, or dividing the number of corresponding cells between each sheet[44]. This "algebraic map" [45], [46], creates an ideal raster map for creating terrain, which is a composite of several raster maps in general geography.

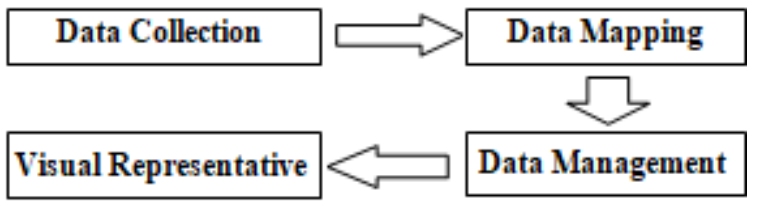

Figure 2: The Research procedure

\section{a) Data Collection}

The flow of data collection begins with data collection from the Makassar City Police Station in the form of motorcycle gang criminal data in Makassar City for the last two years, i.e., from 2015 to 2016, then the data has attribute data and spatial data in the form of case occurrence, location of subdistrict and time the occurrence of any criminal acts committed by motorcycle gangs. The other supporting data such as population data and socio-economic condition in all sub-districts in Makassar City obtained from BPS (Statistic Central Agency) of Makassar City, Geospatial Information
Agency (BIG) and direct observation to the field to determine and see hotspots of motorcycle gang criminality.

The data used in this research are:

- Hotspot data of motorcycle gang from Makassar Police Office

- Map of Makassar City Administration.

- Data Number and Population Density of Makassar City is the latest from BPS Makassar

- Field Survey Data.

\section{b) Data Mapping}

The data of motorcycle gang criminality that has obtainedplaced on the map according to the location of the incident. Then the attribute data of the theft event is inserted into a simple table structure.

\section{c) Data Management}

Mapped data will then be processed using tactical crime, crime analysis, crime density, overlay and regulatory analysis methods. Also, some simple statistical techniques will also apply. The output of this simple analytical management is a simple comparison chart. The software used in processing and data analysis includes:

- ArcGIS version 10.3 as software for data management and visualization.

- IBM SPSS (Statistical Package for the Social Sciences) is used to analyze the relationship between density and population to the crime rate.

\section{d) Visual Representation}

Visual representation method is density Mapping which is used to see directly the intensity of criminal gang crime events related to population density in Makassar City.

\section{Result and Discussion}

Comparing population density maps and crime hotspots plans, it can see the tendency of the motorcycle gang's crime. The population data and criminal hotspots that compared are 2014 population data,and crime hotspots data of 2015 and 2016 , one of the other benefits with this comparison technique is that it can be one of the indicators in determining prediction patterns of crime[47].

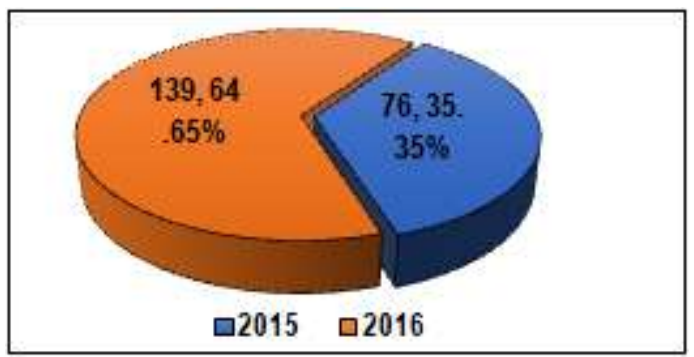

Figure 3: Number of criminal cases in Makassar City

Figure 3 shows the number of criminal rates committed by motorcycle gangs in 2015 there are 76 events or about $35.35 \%$ while in 2016 it increased very sharply to 139 occurrences or about $64.65 \%$. Then from the police data related to the age of the perpetrators of criminal motorcycle gangs ranged between 15-20 years. Many of those arrested by the police are still in school. The motivation of the teens

\section{Volume 7 Issue 4, April 2018




\section{International Journal of Science and Research (IJSR) \\ ISSN (Online): 2319-7064}

Index Copernicus Value (2016): 79.57 | Impact Factor (2017): 7.296

to join the motorcycle gang is also to gain self-confession. Motorcycle gangs provide the success that teenagers do not get in school, home, and neighborhood. The level of courage determines success in motorcycle gangs in taking risks.

Teenagers prefer to drive at high speed. However, racial races very rarely held. Eventually, they vent wild racing on public roads that have the potential to harm themselves and others. Formerly a motorcycle gang just a group of teenage kids who like to race fast with the motor, both day and night. They do motor racing on public streets. However, lately, the motorcycle gang began to disrupt the public, even into a brutal criminal act that caused many victims died due to violent robbery including the members of the group itself.

Indeed, very many factors that cause teenagers to stop the motorcycle gangs. However, one of the leading causes, why teenagers choose to join a motorcycle gang, is the lack of parental concern and affection[48]. It could be because they are too busy their parents with work, so the attention and love for his son only expressed in material form. Though matter cannot replace their thirst for the friendship and care of parents[49].

Everyone, wants recognition, attention, praise, and affection from the environment, especially from parents or family, because naturally parents and family have a powerful emotional bond[50]. When recognition, attention, and affection do not keep them at home, they will look elsewhere. One of the most comfortable places they can find to get that recognition is in the environment of their friends. Unfortunately, harmful activities often become the choice of broken home children as a way to gain the attention of their existence. Another factor that also serves as the reason why today's teenagers choose to join motorcycle gangs is their lack of means or media to positively self-actualize[51].

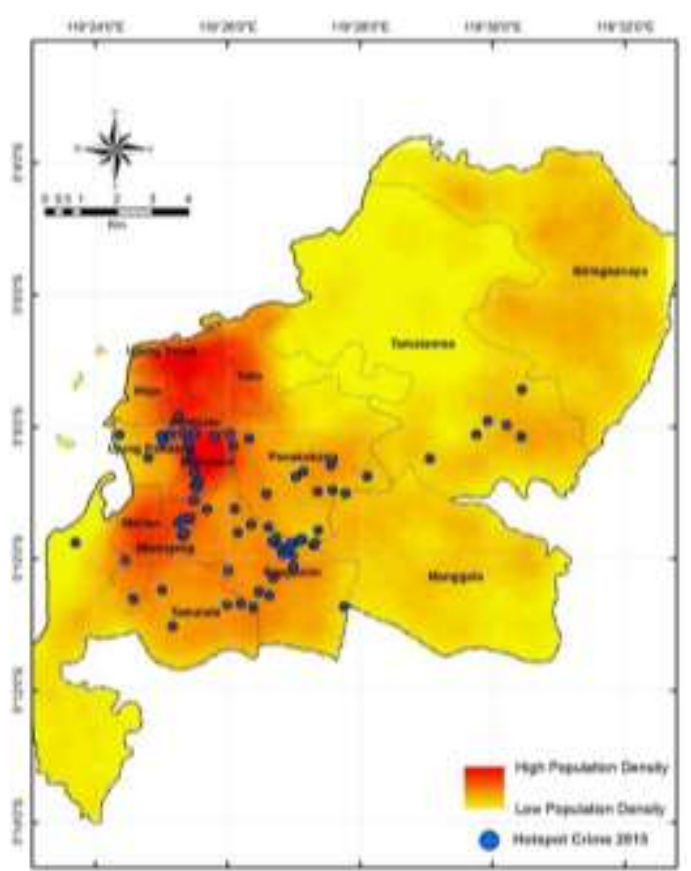

Figure 4: Overlapping between population density and hotspots distribution of robberies, the year 2015

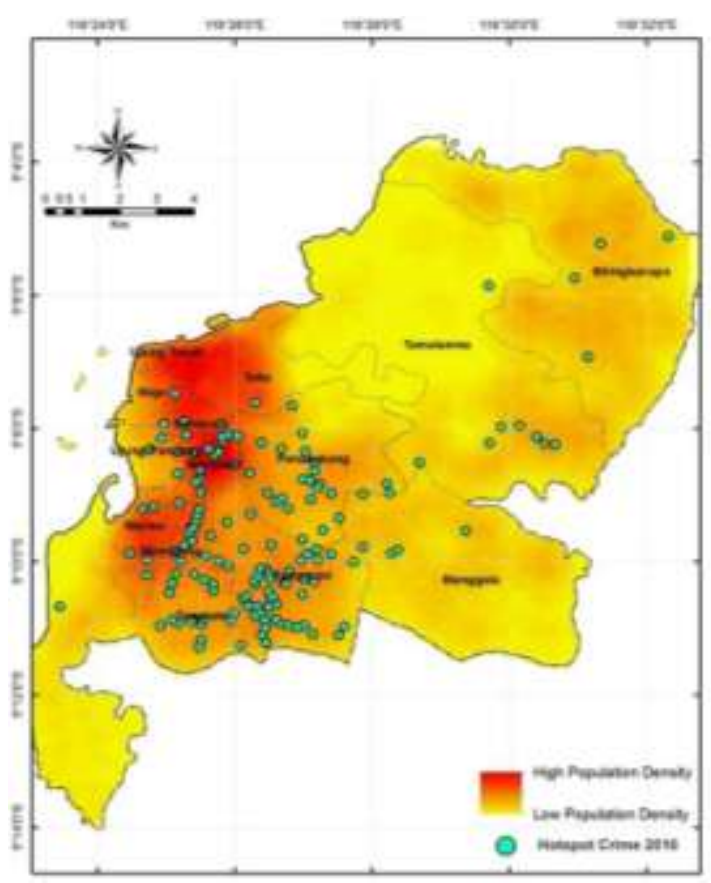

Figure 5: Overlapping between population density and hotspots distribution of robberies, the year 2016

It also shown in Fig. 4 and Fig. 5, from spatial analysis with ArcGISsoftware using overlay (overlapping data) between hotspot density map with population density, shows that hotspot location of motorcycle gang both 2015 and 2016 tend to focus on areas with high population density such as Makassar and Mamajang sub-districts, but for 2016 there are changes in criminal patterns such as the number of new hotspots with high crime density spreading to densely populated areas such as Rappocini, Pannakukang and partly Tamalate.

The emergence of new hotspots in 2016 indicates that the coverage of criminal gang areas is increasingly extensive and varied, not only varying by the location of hotspots but also varying in time (day and night).

The several factors that cause it are:

a) Number of new motorcycle gang players

b) Most perpetrators avoid events in the same place, so the case is not easy to predict, so they continue to mobilize.

c) The development of housing, where the construction tends to areas less dense and far from the reach of the police station

Believed crime density has at least three benefits when compared with criminal interpretation:

First, crime density focuses more on the location of the crime than the place of the suspect or victim, which is the center of public attention and law enforcement (police). Because it is very difficult or sometimes impossible to obtain the residential address of the criminals and their culprits, calculating the density of offenders in any location or environment is a very efficient technique[52].

Secondly, crime density is a balanced representation or indicates the average criminal incidence through space. Usually,some events in the geographic region can produce images of criminal spatial patterns by eliminating prejudices

Volume 7 Issue 4, April 2018 www.ijsr.net 


\section{International Journal of Science and Research (IJSR) \\ ISSN (Online): 2319-7064}

Index Copernicus Value (2016): 79.57 | Impact Factor (2017): 7.296

caused by some existing measures. Along with the presence of GIS technology, it is technically able to measure the polygon region that some size is uncertain. Furthermore, it is also possible to use GIS to calculate criminal density in a very accurate way under actual conditions. For example, if a lake is within the boundaries of an area of authority, public speaking, it is likely to be very small to have offenders in the lake rather than the territory in it. GIS can be used to reduce the volume of water from the area of authority and calculate the actual criminal density by dividing some events only on the land area[53].

Thirdly, crime density is best suited to illustrate criminal intensity in urban environments although it can be used on different geographic scale ranges from local to national. Using crime density can describe the spatial depth of criminals through the geographic area and the better the level, the more accurate the crime density, only because a clear criminal spatial pattern can record if the smallest things can use, such as a suitable scale. And also, crime density has no fundamental foundation on the distribution of population, so even criminal density in a sub-district with a comprehensive and diverse area can be objectively realized. In fact, crime density can efficiently describe the close relationship between demographic characteristics and the level of criminality in the environment[52].

Low SES or low demographic characteristics, minority concentration and high population density tend to have a high criminal frequency, high SES environments or high demographic characteristics, low population densities dominated by white residents are likely to have an illegal low. Therefore, crime density is an appropriate indicator to describe both geographical and demographic dimensions in crime through the environment and can show more accurate and credible criminal images for the general public and law enforcement (Zhang \& Peterson 2007).

Table 1: Correlation CoefficientCrime, and Density

\begin{tabular}{|c|c|c|c|}
\hline \multirow{2}{*}{ Crime } & & Crime & Density \\
\cline { 2 - 4 } & CorrelationCoef. & 1.000 & $.411^{*}$ \\
\hline \multirow{2}{*}{ Density } & Sig. &. & .042 \\
\cline { 2 - 4 } & CorrelationCoef. & $.411^{*}$ & 1.000 \\
\cline { 2 - 4 } & Sig. & .042 &. \\
\hline
\end{tabular}

*. Correlation is significant at the 0.05 level (2-tailed).

Table 1 shows the results of the analysis of the relationship between population density on the level of criminality that occurred. With a total of 14 data, there is a significant correlation between population density and crime rate with relationship value 0.411 and probability level (sig) 0.042 .

The more crowded a city will be the higher the likelihood of crime in the city. According to the theory there are several factors that cause this to happen: the advantage of criminal activityto the town is higher (seen from the property of the victim) when compared to the village, the possibility of capture of criminals in urban areas will be smaller due to the density of the population in the city and pull the town against the individual action crime.It is by research [54]-[56], that the higher the population density, themore elevated the crime rate.
According to [57], states that one cause of crime among others influenced by social factors,i.e., population density. High population density and low economic levels lead to high crime rates, as well as inadequate security levels. [58], various social patterns that weaken the family and communal bonds bind with the population and result in social disorientation. This social disorganization is believed to be the source of evil because society is not holding on to prevailing values that are too self-centered for its interests [59]. Crime is more due to social disorganization, not individuality. Urban areas with social disorder result in crime transmitted between one generation to the next [60].

On violent crime incidents. In the study conducted [61], in areas with high levels of density, the screams and screams of crime victims may be heard louder and then from the individual or community who listened to the cries came the urge to help the victim.

Under conditions of high population density, there are situations where criminals and targets meet indirectly, but despite high frequency but security levels are still very less than expected by society [24]. Space awareness and space of criminal acts are very different as well as the distribution of opportunities for property and violent crime. This scale of analysis can be considered relatively significant in the sense that the observation unit (block) is relatively small

[62], [63], describes a positive relationship between population density and robbery using victim investigation data. The study obtained:

a) Opportunity means that the higher the population density, the higher the possibility of robbers will find the victim.

b) As predicted [64], the interpretation of the "subculture" of an active city based on the fact that the same feelings are found and interconnected under conditions of cooperative regimes and weak interactions. Promote and criminal areas with activities.

c) Regional, it is intended to believe that the patterns of history, tradition and reconciliation record high-level urban crimes and will stick for a long time

Because the density of the population density somewhere will undoubtedly affect the level of welfare of the population itself. In fact, it is not impossible will appear conflict and social crime. Such unemployment will do various ways to meet the needs of his life. In these conditions will be prone to multiple criminal actions such as theft and fraud. The denser an area, the less likely it will be the equity in every aspect of the lives of its population.

Due to population density. Here I will explain the problems that will arise in the future, namely: Crime, crime rates are increasing with the population, the competition to get money is getting narrower. It will trigger fierce competition which then allows it to have an impact on the crime rate. For example, the existence of pickpocketing, robbery, and violence

Maltus theory [65], human lust cannot be contained and detained. Consequently,the population growth is much faster than the growth of food. Furthermore, Maltus adds that the 


\section{International Journal of Science and Research (IJSR) \\ ISSN (Online): 2319-7064}

Index Copernicus Value (2016): 79.57 | Impact Factor (2017): 7.296

population increases not too fast because of the obstacles to human suffering in the form of crime and misery, the existence of preventive factors that reduce inequality between the amount.

Crime other than caused by economic factors, one of the reasons is from socio-cultural factors. The number of conflicts, murders caused by conflicts that occur within the community. From a social point of view, it can be seen from social jealousy because of the high social status of a person that makes a person with a low social state desperate to commit criminal acts such as destruction of cars owned by wealthy people, looting of shops, demolition of houses or shops in the heart of the city center areas by throwing glasses of houses or shops of others with irresponsibility.

\section{Conclusion}

The density value shows that there is a relation between population density to the spread pattern of criminal hotspots wherein 2015 the distribution pattern of crime hotspots concentrated in areas with high population density, but in 2016 the distribution pattern of crime hotspots spread evenly not only in high population areas density but has spread to the medium population density region.

The density of the urban population itself is an essential issue for a country and the number of people there are factors causing population density, among others, birth factors, availability of employment factors, uneven development factors, customary or cultural factors, Given the frequency of the population in a particular place will affect the welfare of the city's community, and this will be the emergence of problems such as crime, unemployment, poverty.

\section{References}

[1] C. A. Mamalian and N. G. La Vigne, The use of computerized crime mapping by law enforcement: Survey results. US Department of Justice, Office of Justice Programs, National Institute of Justice, 1999.

[2] R. Boba, Introductory Guide to Crime Analysis and Mapping. United State: Community Oriented Policing Services U.S. Departement of Justice, 2001.

[3] F. Wang, "Why police and policing need GIS: An overview," Ann. GIS, vol. 18, no. 3, pp. 159-171, 2012.

[4] A. A. Braga, A. V Papachristos, and D. M. Hureau, "Hot spots policing effects on crime," Campbell Syst. Rev., no. 8, pp. 1-97, 2012.

[5] A. A. Braga and D. Weisburd, Policing problem places: Crime hot spots and effective prevention. Oxford University Press on Demand, 2010.

[6] K. T. Geurs and J. R. Ritsema van Eck, "Accessibility measures: review and applications. Evaluation of accessibility impacts of land-use transportation scenarios, and related social and economic impact," RIVM Rapp. 408505006, 2001.

[7] J. E. Eck, S. Chainey, J. G. Cameron, M. Leitner, and R. E. Wilson, Mapping Crime: Understanding Hot Spots. Washington, DC: National Institute of Justice, 2005.

[8] K. D. Harries, "Mapping crime: Principle and practice," US Department of Justice, Office of Justice Programs, National Institute of Justice, Crime Mapping Research
Center, 1999.

[9] L. W. Sherman, P. R. Gartin, and M. E. Buerger, "Hot spots of predatory crime: Routine activities and the crimiology of place," Criminology, vol. 27, no. 1, pp. 27-55, 1989.

[10]A. Abbott, "Of time and space: The contemporary relevance of the Chicago School," Soc. Forces, vol. 75, no. 4, pp. 1149-1182, 1997.

[11] J. E. Eck and D. Weisburd, "Crime and place, crime prevention studies," Monsey, NY Crim. Justice Press. EckCrime Place, Crime Prev. Stud., 1995.

[12] R. L. Block and C. R. Block, "Space, place and crime: Hot spot areas and hot places of liquor-related crime," Crime and place, vol. 4, no. 2, pp. 145-184, 1995.

[13] P. P. Brantingham and P. P. Brantingham, "Criminality of place," Eur. J. Crim. Policy Res., vol. 3, no. 3, pp. 526, 1995.

[14]P. J. Brantingham and P. L. Brantingham, Environmental criminology. Sage Publications Beverly Hills, CA, 1981.

[15]R. J. Simon, Women and crime. Lexington Books Lexington, MA, 1975.

[16] L. E. Cohen, J. R. Kluegel, and K. C. Land, "Social inequality and predatory criminal victimization: An exposition and test of a formal theory," Am. Sociol. Rev., pp. $505-524,1981$.

[17] L. E. Cohen and M. Felson, "On estimating the social costs of national economic policy: A critical examination of the Brenner study," Soc. Indic. Res., vol. 6, no. 2, pp. 251-259, 1979.

[18]L. E. Cohen and M. Felson, "Social change and crime rate trends: A routine activity approach," Am. Sociol. Rev., pp. 588-608, 1979.

[19]F. Bacon, Francis Bacon: the new organon. Cambridge University Press, 2000.

[20] J.-J. Rousseau, Il contrattosociale. Edizioni Mondadori, 2015.

[21]C. Lombroso, Criminal man. Duke University Press, 2006.

[22] A. Von Hirsch, "Proportionality in the Philosophy of Punishment," Crime and Justice, vol. 16, pp. 55-98, 1992.

[23] T. Herchenrader and S. Myhill-jones, "GIS supporting intelligence-led policing," Police Pract. Res., vol. 16, no. 2, pp. 136-147, 2015.

[24] K. D. Harries, "Property Crimes and Violence in United States: an analysis of the influence of population density," Int. J. Crim. Justice Sci., vol. 1, no. 2, pp. 2434, 2006.

[25] J. B. Calhoun, "Population density and social pathology," Sci. Am., vol. 206, no. 2, pp. 139-149, 1962.

[26] J. Li and J. Rainwater, "The real picture of land-use density and crime: A GIS application," in Proceedings of the 20nd annual ESRI International User Conference, 2000.

[27] J. D. Morenoff, R. J. Sampson, and S. W. Raudenbush, "Neighborhood inequality, collective efficacy, and the spatial dynamics of urban violence," Criminology, vol. 39, no. 3, pp. 517-558, 2001.

[28] R. J. Sampson and W. B. Groves, "Community structure and crime: Testing social-disorganization theory," Am. J. Sociol., vol. 94, no. 4, pp. 774-802, 1989.

[29] [29] R. J. Sampson and J. D. Wooldredge, "Linking the

\section{Volume 7 Issue 4, April 2018




\section{International Journal of Science and Research (IJSR) \\ ISSN (Online): 2319-7064 \\ Index Copernicus Value (2016): 79.57 | Impact Factor (2017): 7.296}

micro-and macro-level dimensions of lifestyle-routine activity and opportunity models of predatory victimization," J. Quant. Criminol., vol. 3, no. 4, pp. 371-393, 1987.

[30]F. B. M. De Waal, F. Aureli, and P. G. Judge, "Coping with crowding," Sci. Am., vol. 282, no. 5, pp. 76-81, 2000.

[31] R. B. Freeman, "The economics of crime," Handb. labor Econ., vol. 3, pp. 3529-3571, 1999.

[32] A. Booth, S. Welch, and D. R. Johnson, "Crowding and urban crime rates," Urban Aff. Q., vol. 11, no. 3, pp. 291-308, 1976.

[33]B. Malinowski, Crime and custom in savage society. Transaction Publishers, 2013.

[34] J. R. Lilly, F. T. Cullen, and R. A. Ball, Criminological theory: Context and consequences. Sage, 2010.

[35] R. Agnew, "Why do criminals offend?: A general theory of crime and delinquency," 2005.

[36]A. Blumstein, Criminal Careers and" Career Criminals," vol. 2. National Academies, 1986.

[37]R. F. Tomlinson, Thinking about GIS: geographic information system planning for managers, vol. 1. ESRI, Inc., 2007.

[38] J. T. Coppock and D. W. Rhind, "The history of GIS," Geogr. Inf. Syst. Princ. Appl., vol. 1, no. 1, pp. 21-43, 1991.

[39] Environmental Systems Research Institute, Redlands. ArcView GIS: the geographic information system for everyone. Environmental Systems Research Institute, 1996.

[40] GIS Lounge, "Commercial GIS Software Applications," GIS Lounge, 2011.

[41] A. Hirschfield and K. Bowers, Mapping and analysing crime data: Lessons from research and practice. CRC Press, 2014.

[42] J. M. Caplan, L. W. Kennedy, and J. Miller, "Risk Terrain Modeling: Brokering Criminological Theory and GIS Methods for Crime Forecasting," Justice Q., vol. 28, no. 2, pp. 361-381, 2011.

[43]E. R. Groff and N. G. La Vigne., "Mapping an opportunity surface of residential burglary," J. Res. Crime Delinq., vol. 38, no. 3, pp. 257-278, 2001.

[44]J. M. Caplan and L. W. Kennedy, Risk Terrain Modeling Compendium. Newark, New Jersey: Rutgers Center on Public Security, 2011.

[45] C. D. Tomlin, A map algebra. Harvard Graduate School of Design Cambridge, MA, 1990.

[46] C. D. Tomlin, "Map algebra: one perspective," Landsc. Urban Plan., vol. 30, no. 1-2, pp. 3-12, 1994.

[47] S. Chainey, L. Tompson, and S. Uhlig, "The utility of hotspot mapping for predicting spatial patterns of crime," Secur. J., vol. 21, no. 1-2, pp. 4-28, 2008.

[48] D. Finkelhor, Childhood victimization: Violence, crime, and abuse in the lives of young people. oxford university Press, 2008.

[49] E. E. Maccoby, "The role of parents in the socialization of children: An historical overview.," Dev. Psychol., vol. 28, no. 6, p. 1006, 1992.

[50]R. P. Rohner, A. Khaleque, and D. E. Cournoyer, "Parental acceptance-rejection: Theory, methods, cross-cultural evidence, and implications," Ethos, vol. 33, no. 3, pp. 299-334, 2005.

[51] K. H. Trzesniewski, M. B. Donnellan, T. E. Moffitt, R.
W. Robins, R. Poulton, and A. Caspi, "Low self-esteem during adolescence predicts poor health, criminal behavior, and limited economic prospects during adulthood.," Dev. Psychol., vol. 42, no. 2, p. 381, 2006.

[52] S. Chainey and J. Ratcliffe, GIS and crime mapping. John Wiley \& Sons, 2013.

[53] M. A. Andresen and G. W. Jenion, "Ambient populations and the calculation of crime rates and risk," Secur. J., vol. 23, no. 2, pp. 114-133, 2010.

[54]R. J. Sampson, "Structural density and criminal victimization," Criminology, vol. 21, no. 2, pp. 276-293, 1983.

[55]D. Shichor, D. L. Decker, and R. M. O'Brien, "Population Density and Criminal Victimization Some Unexpected Findings in Central Cities," Criminology, vol. 17, no. 2, pp. 184-193, 1979.

[56]M. A. Andresen, "Crime measures and the spatial analysis of criminal activity," Br. J. Criminol., vol. 46, no. 2, pp. 258-285, 2005.

[57] E. Ferri, Criminal sociology. Little, Brown, 1917.

[58] R. E. Park and E. W. Burgess, Introduction to the Science of Sociology. University of Chicago Press Chicago, 1921.

[59] Wickersham Commission, United States., C. R. Shaw, and H. D. McKay, Social factors in juvenile delinquency. Government Press, 1931.

[60] C. R. Shaw and H. D. McKay, "Juvenile delinquency and urban areas," Chicago, Ill, 1942.

[61]R. B. Felson, Violence \& gender reexamined, vol. 21. American Psychological Association Washington, DC, 2002.

[62] B. Boland, "Patterns of urban crime," Sample Surv. Vict. crime, pp. 27-41, 1976.

[63] W. G. Skogan, Sample surveys of the victims of crime. Ballinger Cambridge, MA, 1976.

[64] M. E. Wolfgang, Urban Crime: In The Metropolitan Enigma, James Q. W. Cambridge, Massachusetts, USA: Harvard University Press, 1968.

[65] T. R. Maltus, An essay on the principle of population, vol. 1. Cosimo, Inc., 2006.

Volume 7 Issue 4, April 2018 www.ijsr.net

Licensed Under Creative Commons Attribution CC BY 